http://doi.org/10.35784/iapgos.2100

\title{
INFOCOMMUNICATION TECHNOLOGIES FOR ASSESSMENT AND PREDICTION OF ENVIRONMENT IMPACT ON HUMAN HEALTH
}

\author{
Oksana Boyko ${ }^{1}$, Nataliya Dorosh ${ }^{1}$, Irena Yermakova ${ }^{2}$, Oleh Dorosh ${ }^{2}, \dot{Z Z a k l i n}_{\text {Grądz }^{3}}$ \\ ${ }^{1}$ Danylo Halytsky Lviv National Medical University, Department of Medical Informatics, Lviv, Ukraine, ${ }^{2}$ International Scientific - Training Centre for Information Technologies \\ and Systems under NAS and MES of Ukraine, Department of Complex Research of Information Technologies, Kyiv, Ukraine, ${ }^{3}$ Lublin University of Technology, Department of \\ Electronics and Information Technology, Lublin, Poland

\begin{abstract}
An innovative concept and the structural organization of a modular system for long-term monitoring, analysis and correction of integrated health indicators of different groups of the population taking into account the impact of environmental factors and extreme conditions is described. The main elements of the system are a module for measuring physiological indicators that characterize the state of human health, a sen sor module for selection and registration of environmental indicators, a data transmission module, a database, a module for comprehensive analysis of indicators, a forecasting module, a set of mathematical models, a module for results displaying. Methods of mathematical modelling and statistics were used to predict health state. The mobile application that allows to assign and take into account changes in environmental performance during physical activity, e.g. training weather conditions, such as temperature, relative humidity and wind speed, as well as the distance and duration of running, is developed. The results can be obtained numerically and graphically on the smartphone screen. The proposed system allows to predict the functional state of person in different environmental conditions. It will allow the user to make the right decision about the duration and intensity of physical activity in certain environmental conditions and choose the appropriate level of physical activity.
\end{abstract}

Keywords: information system, medical gadgets, mobile applications, human health state, forecasting

\section{TECHNOLOGIE INFORMACYJNO-KOMUNIKACYJNE W OCENIE I PROGNOZOWANIU WPLYWU CZYNNIKÓW ŚRODOWISKOWYCH NA ZDROWIE LUDZI}

Streszczenie. W artykule została opisana nowatorska koncepcja i strukturalna organizacja modułowego systemu do dtugoterminowego monitorowania, analizy i korekty zintegrowanych wskaźników zdrowotnych różnych grup ludności z uwzględnieniem wpływu czynników środowiskowych $i$ warunków ekstremalnych. Głównymi elementami systemu sa: moduł do pomiaru wskaźników fizjologicznych charakteryzujacych stan zdrowia człowieka, modut czujników do selekcji i rejestracji wskaźników środowiskowych, moduł transmisji danych, baza danych, moduł do kompleksowej analizy wskaźników, modut do prognozowania, zestaw modeli matematycznych, modul do wyświetlania wyników. Do przewidywania stanu zdrowia wykorzystano metody modelowania matematycznego i statystyki. Aplikacja mobilna umożliwiajaca przypisywanie i uwzględnianie zmian efektywności środowiskowej podczas aktywności fizycznej, np. opracowywane sq warunki pogodowe podczas, których odbywa się trening, takie jak temperatura, wilgotność względna i prędkość wiatru, a także dystans $i$ czas trwania biegu. Wyniki można uzyskać numerycznie i graficznie na ekranie smartfona. Zaproponowany system pozwala przewidzieć stan funkcjonalny czlowieka w różnych warunkach środowiskowych. Pozwoli użytkownikowi na podjęcie właściwej decyzji co do czasu trwania i intensywności aktywności fizycznej $w$ określonych warunkach środowiskowych oraz na wybór odpowiedniego poziomu aktywności fizycznej.

Słowa kluczowe: system informacyjny, gadżety medyczne, aplikacje mobilne, stan zdrowia człowieka, prognozowanie

\section{Introduction}

Monitoring and controlling of human health is one of the important priorities of the health care system worldwide. This issue is especially important during a pandemic.

Currently, there are a large number of different electronic medical devices, sensors, gadgets, mobile applications that allow to measure and monitor various physiological indicators that characterize the state of human health. Methods and means of obtaining medical information in the mode of remote access with the use of modern infocommunication technologies are actively introduced. The amount of received information is extremely large and constantly growing. Therefore, the developing of systems for the organization, analysis and management of information processes and flows is an important task in monitoring and controlling the health of the population [4-5].

Various external factors have a significant effect on human health. For example, weather conditions, temperature, humidity, air pollution and other environmental factors can significantly affect a person's well-being and pose a threat to their health. It is also important to take into account the influence of environmental factors during the training of athletes and sports competitions in order to achieve the highest results.

Computer monitoring together with the capabilities of modern information and mobile technologies opens up new opportunities and a fundamentally different level of knowledge that was previously impossible to obtain. As a result, it becomes possible to prevent diseases and their complications.

It is important to develop methods and tools for assessing and forecasting human health, taking into account the various external influences of the environment. A promising direction for solving such problems is the combination of capabilities of modern infcommunication technologies and methods of mathematical modelling.

\section{Analysis of the current state of infocommunication technologies development for population health assessment}

Modern systems for monitoring, evaluation and control of human health are based on infocommunication technologies. Such systems are multifunctional and contain a large number of devices for measuring human health indicators. Smartphones and specialized applications, as well as tools for transferring indicators from devices to a smartphone can be used for the collection, storage and processing of indicators [6-7,9].

The concept of an innovative modular infocommunication system with feedback for long-term monitoring, analysis and correction of integrated indicators of human health is described in [3]. The system is developed on the basis of client-server architecture and includes a module of user identification, a module of data transmission from medical sensors and devices (medical gadgets), a module of verbal evaluation, a module of local database formation, a module of processing the measurement results and examination, a module for quick analysis and displaying the results. A global database is formed on the server, which stores information about complex indicators that characterize the health of users and risk groups that can be identified.

Express analysis makes it possible to characterize the current state of user health and inform about the dangerous changes in the body. The analysis is performed by professional doctors for early detection of possible abnormalities. Examples of implementation and practical applications of the main modules of such system are described in [1]. 


\section{Methods and tools for comprehensive assessment of the impact of environmental factors on human health}

Comprehensive assessment of the impact of the environment on human health may include the use of geographic information technologies and methods of mathematical statistics with additional health criteria analysis. It allows to detect the areas with high health risk.

A method of comprehensive assessment of the environment impact on human health is described in patent [11]. The analysis of health state taking into account the environmental situation is performed on the basis of information technologies OracleDiscoverer, Statistica, Mapinfo. The differentiated approach is used to choose the criteria and parameters of the population health state and estimate the effects of environmental factors, taking into account personalized medical and environmental information

This method allows to integrate medical and environmental data for a generalized quantitative assessment of human health in specific areas, as well as to determine the importance of individual environmental factors that have the greatest impact on health state. The developed and tested method of comprehensive assessment of the impact of environmental factors on human health, which represents a step-by-step study and analysis of data of medical and ecological monitoring of different levels taking into account key elements of interaction in the system and specifics of the region. It allows receiving the most objective information about the degree and nature of the impact of the environmental situation on human health at the lowest possible cost.

Implementation of the method of comprehensive assessment of the impact the environmental factors on human health, which is a step-by-step study and analysis of medical and environmental monitoring data at different levels, taking into account the interaction of environmental factors affecting human health in the system and the region allows obtaining effective information through the use of specialized telemedicine systems.

A method of creating a mobile information system for personalized medicine, which use a smartphone as a basic element and a set of mathematical models that describe the functional state of human in different environmental conditions, during the changes of air temperature, humidity and other environmental factors is presented in [10].

\section{Conceptual organization of information and communication system}

The concept of innovative modular infocommunication system for long-term monitoring, analysis and correction of integrated mental health and physical health of different population groups is developed. It is based on analysis of functional and analytical capabilities of modern means of measuring and evaluating the indicators that characterize the state of human health with the help of medical sensors, devices and mobile applications for smartphones. It also allows to estimate the influence of external environmental factors on person's health state.

To solve these problems, we propose the modular concept of creating a multifunctional information and communication system of the combined type, which with the help of modern mobile devices (smartphones, tablets, etc.), medical sensors (gadgets) and developed software allows to:

1. Detect and control:

- cognitive impairment (based on the system of tests and EEG);

- disorders of the cardiovascular system (heart rate, blood pressure, HRV, etc.);

- stress level

- metabolic disorders (fat, sugar...);

- violation of the state and functions of the musculoskeletal system;

- level of physical activity (activity-inactivity);
- violation of the daily sleep-wake cycles (circadian rhythmsCR);

- other parameters that characterize the state of human health;

2. Conduct a comparative rapid analysis (norm - limit statedeviation from the norm) to determine risk groups and disease prevention;

3. Define integrated indicators for comprehensive and professional analysis;

4. Investigate the impact of environmental factors on human health;

5. Investigate the influence of some parameters on others (multiparametric analysis):

- the effect of stress (for example, on the state of cardiovascular system and cognitive functions);

- the impact of physical activity (inactivity);

- the influence of external environmental factors;

- the influence of style and quality of food;

- the impact of circadian rhythms violations;

6. Conduct screening studies for different age, gender and other population groups;

7. Predict the state of human health in different conditions using mathematical modelling;

8. Make recommendations for functions adjustment and carry out their control after carrying out appropriate adjustment measures.

\section{Structural organization of the system}

The structural organization of the system is presented in Fig.1.

The main elements of the system:

- M1-Module for measuring physiological indicators that characterize the state of human health;

- M2-Sensor module for selection and registration of environmental indicators;

- M3-Data transmission module;

- M4-Database;

- M5-Module for comprehensive analysis of indicators;

- M6-Forecasting module;

- M7-Set of mathematical models;

- M8-Results display module.

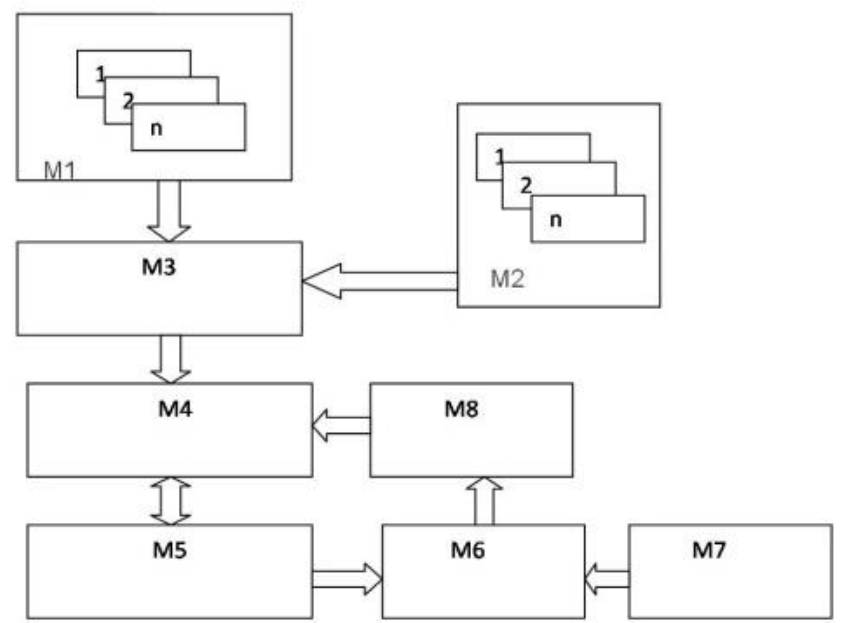

Fig. 1. The structural organization of the system

Module for measuring physiological indicators M1 contains a set of medical gadgets, microdevices and sensors that allow to record various parameters of human health: temperature, heart rate, blood pressure, skin conductivity, etc. $[2,8]$.

The sensor module for selection and registration of environmental indicators M2 contains a set of sensor devices that measure or assign indicators of the environment condition (air or water temperature, humidity, gassiness, etc.) 


\section{Practical application of the system}

During the practical application of the proposed system for measuring physiological parameters that characterize the human health state, medical gadgets and mobile applications for smartphones of various types were used.

Fig. 2 shows the fitness bracelet MioFuse, which allows to measure heart rate in relaxation and during physical activity, as well as during sleep in different conditions.

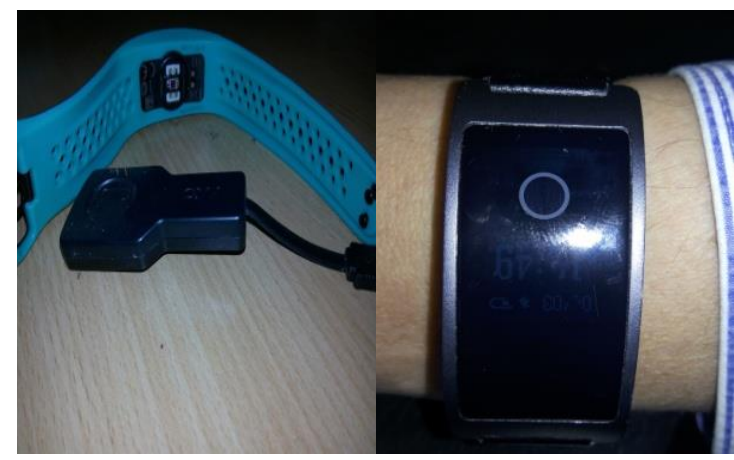

Fig. 2. MioFuse medical gadget

The measurement results can be viewed on a smartphone with the help of MioGo mobile application. The Built-in Extract option allows to transfer the measurement results to the server and record them in spreadsheets. The results of the heart rate measuring during physical activity are shown in Fig. 3.

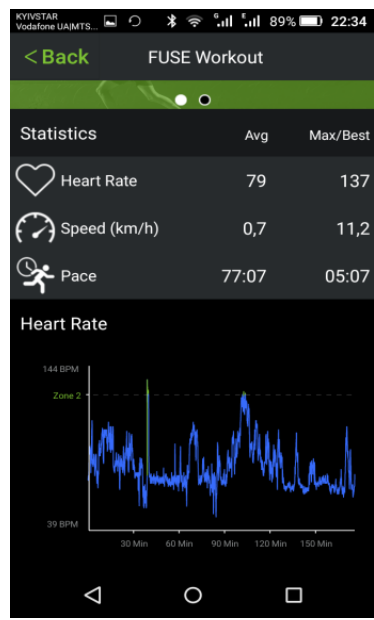

Fig. 3. The results of the heart rate measuring during physical activity

Fig. 4 shows the recording of heart rate during sleep.

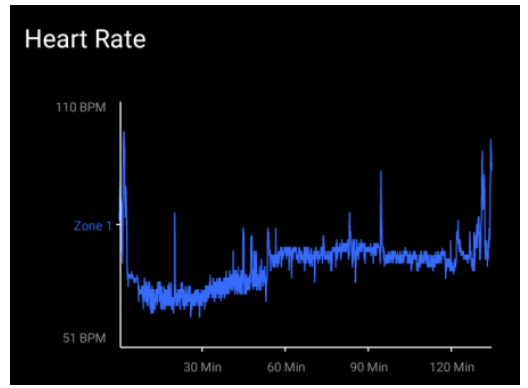

Fig. 4. The recording of heart rate during sleep

The result of data representation in a spreadsheet environment with the calculation of the cardiocycles duration are shown in Fig. 5.

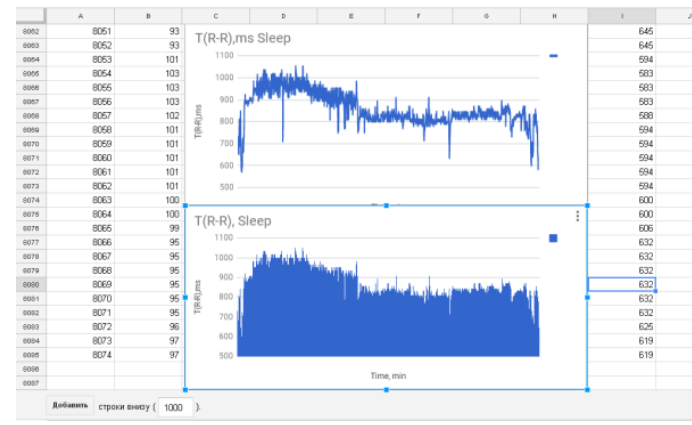

Fig. 5. Data representation in a spreadsheet environment with the calculation of the cardiocycles

The system can provide the ability to compare the results of heart rate measurements in different environmental conditions.

The mobile application that allows to assign and take into account changes in environmental conditions during physical activities has been developed. The user can specify training weather conditions, temperature, relative humidity and wind speed (Fig. 6, 7). The running distance and duration it is also assigned. The longer the workout the more exhausting it is for the body.

All these parameters affect the calculations of water loss and body temperature.

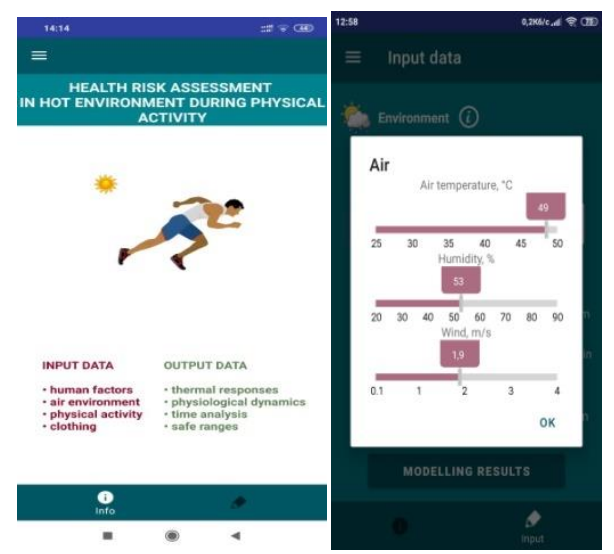

Fig. 6. Selection of input data during the physical activity

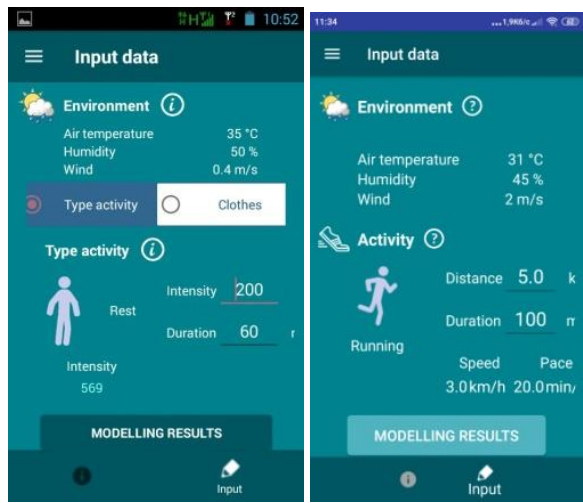

Fig. 7. Choosing the activity type and environmental parameters - temperature, humidity, wind speed

Fig. 8 demonstrates how a person's body temperature will change during a running, as well as how much water will be lost during sweating. The slider below allows to consider these losses in the dynamics and thus explore the losses during each minute of training. This will allow athletes or other categories of the population to assess their ability to avoid overload with harmful or fatal consequences. 


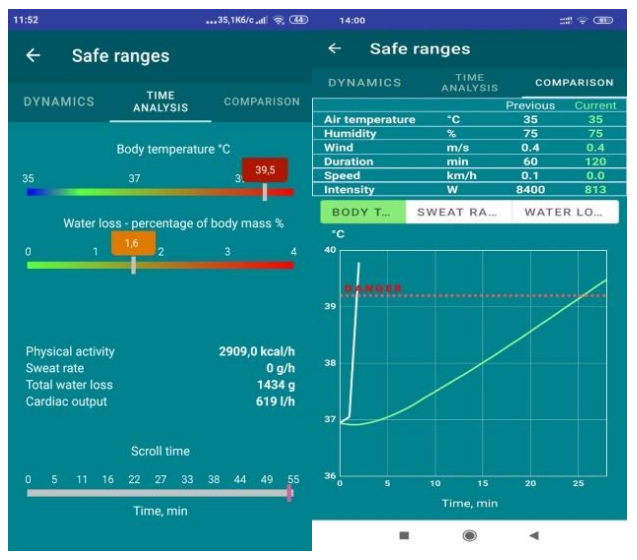

Fig. 8. Presentation of results

The plots show changes in water loss and body temperature over time. The program provides the displaying of two workouts for comparison, so there are two lines in the plot. In addition, the DANGER scale shows the limit, when the transition of any parameter beyond this limit shows a health hazard. All historical trainings are stored in the database, but at the moment it is impossible to access them through the application itself. At the same time, the data is available on the server for further analysis and processing.

\section{Conclusions}

An intelligent infocommunication modular system for assessing and forecasting human health taking into account the impact of environmental factors has been developed. A mathematical modeling module is provided in the system to predict possible changes in health status and to calculate safe health limits.

The client-server architecture of the system provides multiuser access to the resources and capabilities of the system. The client part is implemented as a smartphone application that allows to perform input, initial control, data transferring to the server, receiving and displaying the results on the screen. The server part of the system consists of a data flow management program, service platform, database with personal information and prediction result database. The results of practical application of the system with the usage of modern mobile technologies and medical gadgets are given.

The proposed system allows to predict the functional state of a person, which will help the user to make the right decision about the duration and intensity of physical activity in different environmental conditions.

\section{References}

[1] Boyko O., Dorosh N., Ilkanych K., Basalkevych O., Yermakova I., Dorosh O. Multifunctional mobile information system with feedback for analysis of human health and improved access to medical services. Proceedings of the $2 \mathrm{nd}$ International Conference on Advanced Information and Communication Technologies (AICT'2017), 168-173 [http://doi.org/10.1109/AIACT.2017.8020092].

[2] Boyko O., Hotra O. Correction of dynamic characteristics of temperature measuring devices. Proc. of SPIE 10808, 2018, 1080858-1-1080858-7.

[3] Dorosh N., Boyko O., Kuchmiy H., Dorosh O., Stepanjuk O, Maritz N. Development the software applications for mobile medical systems based on OS Android. Proceedings of the XIII International Conference "Modern Problems of Radio Engineering, Telecommunications and Computer Science" 2016, 808-810 [http://doi.org/10.1109/TCSET.2016.7452190].

[4] Garge G. K., Balakrishna C., Datta S. K.: Consumer health care: Current trend in consumer health monitoring. IEEE Consumer Electronics Magazine. 7(1), 2018, 38-46.

[5] Havlik J., Dvorak J., Parak J., Pokorny M.: Possibilities of personal health status monitoring. European Journal of Biomedical Informatics 10(1), 2014, 11-17.

[6] McCarthy M., Spachos P.: Using mobile environment sensors for wellness monitoring. IEEE 21st International Workshop on Computer Aided Modelling and Design of Communication Links and Networks (CAMAD), 2016, 135-139 [http://doi.org/10.1109/CAMAD.2016.7790344].

[7] McCarthy M., Spachos P.: Wellness assessment through environmental sensors and smartphones. IEEE International Conference on Communications (ICC), 2017, 1-6, [http://doi.org/10.1109/ICC.2017.7997416].
[8] Sharma S., Tripathi M. M., Mishra V. M.: Survey paper on sensors for body area network in health care. International Conference on Emerging Trends in Computing and Communication Technologies (ICETCCT), 2017, 1-6.

[9] Surtel W., Maciejewski M., Cieślar M.: A model of a mobile Android application for environmental patient monitoring. Informatyka, Automatyka, Pomiary w Gospodarce i Ochronie Środowiska - IAPGOS 3(4), 2013, 38-40.

[10] Yermakova I. I, Nykolaenko A. M., Solopchuk Y. M., Hrytsiuk O. V., Tadeeva Y. P.: Informatsiina smartfon tekhnolohiia dlia prohnozu stanu zdorovia liudyny. V Ekstremalnykh Umovakh Seredovyshcha. Kibernetyka ta Obchysliuvalna Tekhnika 4(194), 2018, 29-38.

[11] Yevstafieva O. V.: Sposib kompleksnoi otsinky vplyvu dovkillia na zdorovia liudyny. Patent of Ukraine, 74216, 2012.

\section{D.Sc. (Tech.) Oksana Boyko \\ e-mail: oxana_bojko@ukr.net}

Oksana Boyko graduated from Lviv Polytechnic State University Faculty of Applied Mathematics. Since 2011 she is the Head of the Medical Informatics Department of Danylo Halytsky Lviv National Medical University.

Her research interests include mathematical modelling, biomedical sensors and embedded systems, medical information systems. She is the author of over 200 scientific and methodological works.

http://orcid.org/0000-0002-8810-8969

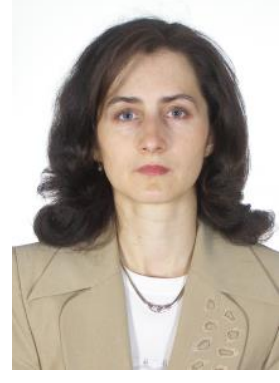

Ph.D. Nataliya Dorosh

e-mail: nvdorosh54@gmail.com

Nataliya Dorosh worked at the Department of Electronic Devices in Lviv Polytechnic State University. Since 2007 she is the Associate Professor at the Medical Informatics Department of Danylo Halytsky Lviv National Medical University.

Her research interests include medical information systems, medical gadgets and m-health system. She is the author of over 100 scientific and methodological works.

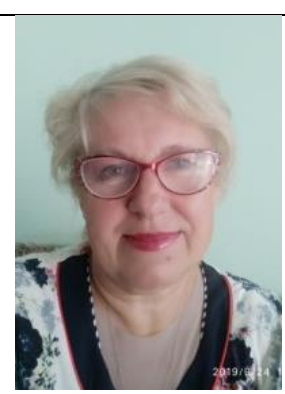

http://orcid.org/0000-0003-4934-6814

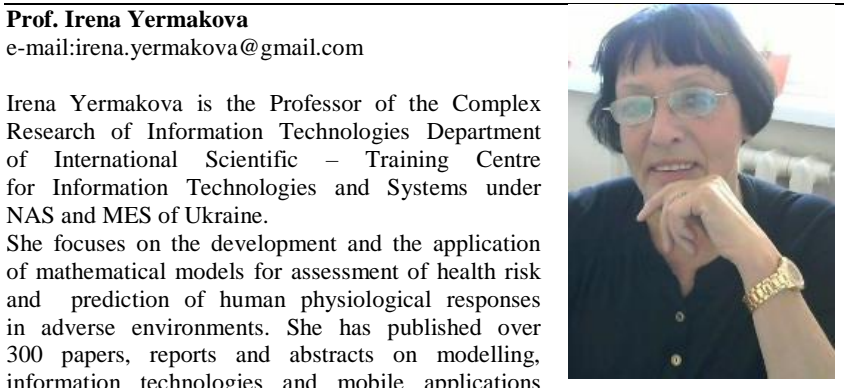
information in extreme environments and exercises.

http://orcid.org/0000-0002-9417-1120

Oleh Dorosh
e-mail: olehdd@gmail.com

Oleh Dorosh graduated from University of KyivMohyla Academy (UKMA)with a master's degree in Computer Science, He finished teaching courses on network administration Under Cisco Certified Network Associate program (CCNA). His main interests are mathematical modeling and mobile application development.

http://orcid.org/0000-0003-2488-0500

\section{M.Sc. Żaklin Grądz}

e-mail: z.gradz@pollub.pl

Assistant in the Department of Electronics and Information Technology of Lublin University of Technology and Ph.D. student at the Electrical Engineering and Computer Science Faculty. Scientific activity includes the analysis of the combustion process in terms of its monitoring and diagnostics.

http://orcid.org/0000-0003-1902-4953 otrzymano/received: 29.07 .2020

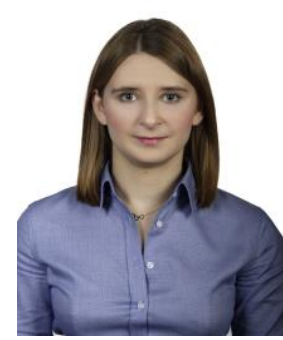

